\title{
Prevalence of Depression and its Associated Factors among Medical Students in International Islamic University Malaysia (IIUM)
}

\author{
Said $\mathrm{AH}^{1}$, Azmi MANH ${ }^{2}$, Mohd Hanapiah $\mathrm{H}^{2}$, Abdullah AW' ${ }^{2}$, Shalihin $\mathrm{MSE}^{1}$ \\ ${ }^{1}$ Department of Family Medicine, Kulliyyah of Medicine, International Islamic University Malaysia. \\ ${ }^{2}$ Final year medical students, Kulliyyah of Medicine, International Islamic University Malaysia.
}

\author{
Keywords \\ Depression, medical students, physical \\ activity, Tahajjud. \\ Corresponding Author \\ Asst. Prof. Dr. Abdul Hadi Said, \\ Department of Family Medicine, \\ Kulliyyah of Medicine, \\ International Islamic University Malaysia, \\ 25200 Kuantan, Malaysia. \\ Email: abdulhadi@iium.edu.my \\ Received: 30 March 2021; Accepted: 27 \\ July 2021 \\ Doi: https://doi.org/10.31436/imjm.v20i4
}

\begin{abstract}
INTRODUCTION: Globally, depression is one of the serious problems reported among medical students. Various studies reported that the prevalence of depression among medical students was high due to multiple risk factors. Therefore, this study aimed to measure the prevalence of depression and its associated factors among medical students in International Islamic University Malaysia (IIUM). MATERIALS AND METHODS: A cross-sectional study was conducted among 500 medical students in IIUM Kuantan. A validated self-reported questionnaire using Depression Anxiety Stress Score 21 was distributed during the second semester of the 2018/2019 session. Descriptive statistics were used to measure the prevalence of depression. Chi-square test, Fisher's exact test, independent sample T-test, and multiple logistic regression were used to determine the association between risk factors and depression. RESULTS: The prevalence of depression was $39 \%$ with $10.5 \%$ of them having severe and extremely severe levels of depression. Multiple logistic regression analysis showed regular physical activity (AOR $=0.64,95 \% \mathrm{CI}$ : $0.42-0.98$ ) and Tahajjud prayer practice (AOR: 0.76, 95\% CI 0.66-0.88) are two protective factors against depression among medical students. CONCLUSION: : About every two out of five IIUM medical students had depression. Regular physical activity and Tahajjud prayer practiced may reduce the risk of depression and should be encouraged.
\end{abstract}

\section{INTRODUCTION}

Health is a state of wellbeing involving physical and mental components. ${ }^{1}$ Those who are in medical field should always be physically fit and mentally sound as their skills and judgments determine the outcome of every patient under their care. However, various studies had found high prevalence of psychological distress among those who were in the medical field including those who have yet to start their carrier as a medical doctor. A systematic review and meta-analysis carried out in 2016 involving more than 150 studies, found the overall pooled crude prevalence of depression among medical students was $27.2 \% .^{2}$ On top of this, it was known that psychological distress such as depression can impair someone's life and increase the risk of mortality from several major causes. ${ }^{3}$

Several international studies in recent years had found high prevalence of depression among medical students. ${ }^{4-10}$
Meanwhile, in local setting, the prevalence of depression among medical students was ranged from $11.1 \%$ to $60.2 \% .{ }^{11-}$ ${ }^{16}$ Based on the previous studies, depression was one of the commonest issues among medical student regardless of the background of the university and the students themselves.

In 2016, a same study had been done involving IIUM medical students where the prevalence of depression found was about $40 \% .{ }^{17}$ However, many students who were involved in the previous study had graduated and new students had enrolled, thus it may affect the latest prevalence of depression. In addition, we wanted to take the opportunity to find the association between Islamic practices which are reading Quran and Tahajjud prayer with depression. Therefore, this study aimed to find out the prevalence of depression among medical student of IIUM and its association with Islamic practices as well as other sociodemographic profiles. 


\section{MATERIALS AND METHODS}

\section{Study design and population}

This study was conducted in International Islamic University Malaysia (IIUM) Kuantan Campus, mid-2019. It was a cross sectional study and convenience sampling method was utilized. According to a recent study among medical students in a local public medical university, the prevalence of depression found was $31.1 \% .14$ Using the single proportion formula, the minimum required sample size was 389 with the precision of 0.05 and considering $20 \%$ non-response rate. We decided to approach all medical students who were available during the study period ranging from first to fifth- year students of the $2019 / 2020$ academic calendar.

\section{Operational definition}

21-items Depression, Anxiety and Stress Scale (DASS-21) was used to measure the mental health component. The result was classified into normal (no depression), mild, moderate, severe and extremely severe depression. Then, mild to extremely severe levels were collectively defined as having depression. Tahajjud prayer was defined as the prayer done after having slept at night between Isha' prayer and Subuh prayer.

\section{Data collection}

Data were collected using a self-administered questionnaire which was divided into two sections. Section A included the sociodemographic and socioeconomic data (year of study, gender, nationality, marital status of student and parents, household income, paternal and maternal educational level), history of family members demise in the past 6 months, family history of psychiatric problems, smoking and regular physical exercise. We also included questions regarding pages of Quran read and Tahajjud prayer performed in a week to find out its association with depression.

Meanwhile, in section B, depression status was evaluated using a validated DASS-21 questionnaire. ${ }^{18}$ Respondents were asked to select the answer from the scale provided $(0,1,2,3)$ for each question. In this study, we only analysed the depression component which were questions numbers $3,5,10,13,16,17$ and 21. As the questionnaire used was a shorter version, the total score yielded was then multiplied by two before being converted to final score. The final score ranged from 0 to 42 . The scores were further classified into normal (no depression), mild, moderate, severe or extremely severe depression. ${ }^{19}$

\section{Data analysis}

SPSS software (version 25) was used to analyse the data. Categorical variables were described as frequencies and percentages. The numerical variables were recorded as median and interquartile range (IQR) as they were not normally distributed. Bivariate analysis for categorical variables was done using Chi-Square and Fisher's Exact Test. Apart from that, the Mann Whitney $U$ test was used to analyse the notnormally distributed numerical variables. A p-value of $<0.05$ was considered statistically significant.

We used multiple logistic regression to assess the relationship between depression with one or more independent variables while controlling for possible confounders. Variables with $p$ $<0.05$ from the bivariate analysis were entered into the multiple logistic regression analysis. We reported the odds ratio (OR) at a 95\% Confidence Interval (CI) to measure the likelihood of associated factors towards depression.

\section{Ethical Consideration}

This study was approved by the Kulliyyah of Medicine and IIUM Research Ethics Committee (IREC) with ID no. IREC 2019-146. Participation in this study was entirely voluntary. All participants who agreed to participate in the survey signed a written consent form. In addition, respondents with a severe and extremely severe level of depression in this study were contacted and advised to seek treatment in IIUM Family Health Clinic.

\section{RESULTS}

500 students from all five batches were conveniently selected and enrolled into this study. 456 students consented and completed the questionnaire making the response rate of $91.2 \%$ achieved. Table I shows the baseline characteristic and prevalence of depression among the respondents. $56 \%$ of the respondents were clinical students (Year 3-5). Majority of the students were from middle income family and above (72.4\%). Only a small number of the respondents were from a broken family $(6.8 \%)$ and had a family history of psychiatric disorders $(7.7 \%)$. The majority $(65.6 \%)$ of respondents did not practice regular physical activity while almost all of them were nonsmokers $(98.7 \%)$. In term of Islamic practices, the median Tahajjud prayer practiced was once a week while the median number of pages of Quran read in a week was 14 pages. Apart from that, the prevalence of depression among respondents was $39.0 \%$. Most of the depressed students were having mild to moderate severity of the symptoms. 
Table I: Baseline characteristics and level of depression of the respondents

\begin{tabular}{|c|c|c|c|}
\hline CHARACTERISTICS & & $\mathbf{n}$ & $(\%)$ \\
\hline \multirow[t]{2}{*}{ Level of study } & Pre-clinical & 199 & 43.6 \\
\hline & Clinical & 257 & 56.4 \\
\hline \multirow[t]{2}{*}{ Gender } & Male & 124 & 27.2 \\
\hline & Female & 332 & 72.8 \\
\hline \multirow{2}{*}{$\begin{array}{l}\text { Marital status of } \\
\text { students }\end{array}$} & Single & 452 & 99.1 \\
\hline & Married & 4 & 0.9 \\
\hline \multirow[t]{3}{*}{$\begin{array}{l}\text { Socioeconomic group } \\
(\mathrm{n}=384)\end{array}$} & B40 & 106 & 27.6 \\
\hline & M40 & 118 & 30.7 \\
\hline & $\mathrm{T} 20$ & 160 & 41.7 \\
\hline \multirow[t]{2}{*}{ Marital status of parents } & Married & 425 & 93.2 \\
\hline & $\begin{array}{l}\text { Divorced/ } \\
\text { separated }\end{array}$ & 31 & 6.8 \\
\hline \multirow[t]{2}{*}{ Smoking } & No & 450 & 98.7 \\
\hline & Yes & 6 & 1.3 \\
\hline \multirow[t]{2}{*}{$\begin{array}{l}\text { Regular physical } \\
\text { Activity }(n=453)\end{array}$} & No & 297 & 65.6 \\
\hline & Yes & 156 & 34.4 \\
\hline \multirow[t]{2}{*}{$\begin{array}{l}\text { Family members demise } \\
\text { in the past six months }\end{array}$} & No & 409 & 89.7 \\
\hline & Yes & 47 & 10.3 \\
\hline \multirow[t]{2}{*}{$\begin{array}{l}\text { Family history of } \\
\text { psychiatric disorder }\end{array}$} & No & 421 & 92.3 \\
\hline & Yes & 35 & 7.7 \\
\hline $\begin{array}{l}\text { Number of pages of } \\
\text { Quran read weekly }\end{array}$ & & & $14(13)^{*}$ \\
\hline $\begin{array}{l}\text { Days of Tahajjud prayer } \\
\text { performed weekly }\end{array}$ & & & $1(2)^{*}$ \\
\hline \multirow[t]{5}{*}{ Depression } & Normal & 278 & 61.0 \\
\hline & Mild & 66 & 14.5 \\
\hline & Moderate & 64 & 14.0 \\
\hline & Severe & 26 & 5.7 \\
\hline & $\begin{array}{l}\text { Extremely } \\
\text { Severe }\end{array}$ & 22 & 4.8 \\
\hline
\end{tabular}

* Median (IQR)

Table II describes the association of study variables with depression. Physical activity, number of pages of Quran read and number of Tahajjud prayer performed were found to be significantly associated with depression.

Multiple logistic regression was used to find the relationship between physical activity, number of pages of Quran read and Tahajjud prayer with depression (Table III). From the multivariate analysis, number of pages of Quran read weekly was revealed to be the confounder. Both regular physical activity and Tahajjud prayer practiced were significantly associated with depression. Those who practiced regular physical activity were less likely to have depression (AOR 0.64, 95\% CI=0.42-0.98, $\mathrm{p}=0.04$ ). Apart from that, Tahajjud prayer practiced was also associated with lower odds of having depression $(\mathrm{AOR}=0.76,95 \% \mathrm{CI}=0.66-0.88, \mathrm{p}<0.001)$.

\section{DISCUSSION}

The prevalence of depression among IIUM medical students found in our study was $39 \%$ and it was lower compared to studies done in the middle east.7,8,10 Our study also had yield lower prevalence of depression compared to the studies done by the researchers from Management and Science University
(MSU). ${ }^{12}$ However, compared to the findings from other public universities, prevalence of depression among medical students in our study was relatively higher. ${ }^{11,12,14,16,20}$ Differences in the results from other studies might be because there were varieties in term of assessment tools that were used, sample size, curriculum, and background of respondents. Apart from that, the prevalence of depression in the current study was similar to the previous study carried out in 2016 in IIUM. ${ }^{17}$ This should be a clear message, that even after three years, the prevalence was still the same indicating that something needs to be done to reduce the prevalence of depression amongst IIUM medical students. Early recognition of those with mental problems are very important. Continuous programme to provide mental and social support such as mentor-mentee programme should be emphasized. Teaching about coping mechanism should be part of the curriculum. Proven interventions such as online mindfulness and relaxation therapy to help students with depression, anxiety and stress should be embraced as part of

Table II: Association between baseline characteristics with depression

\begin{tabular}{|c|c|c|c|c|c|c|c|c|}
\hline \multirow{3}{*}{ Variables } & \multicolumn{6}{|c|}{ Depression } & \multirow{3}{*}{$\begin{array}{c}\text { Chi } \\
\text { square }\end{array}$} & \multirow{3}{*}{$P$ value } \\
\hline & \multicolumn{3}{|c|}{ No } & \multicolumn{3}{|c|}{ Yes } & & \\
\hline & & n & $(\%)$ & & $\mathbf{n}$ & $(\%)$ & & \\
\hline \multicolumn{9}{|l|}{ Level of study } \\
\hline $\begin{array}{l}\text { Pre- } \\
\text { clinical }\end{array}$ & 131 & & 65.8 & 68 & & 34.2 & 3.511 & 0.061 \\
\hline Clinical & 147 & & 57.2 & 110 & & 42.8 & & \\
\hline \multicolumn{9}{|l|}{ Gender } \\
\hline Male & 73 & & 58.9 & 51 & & 41.1 & 0.314 & 0.575 \\
\hline Female & 205 & & 61.8 & 127 & & 38.3 & & \\
\hline \multicolumn{9}{|c|}{ Marital status of student } \\
\hline Single & 276 & & 61.1 & 176 & & 38.9 & 0.204 & $0.645^{+}$ \\
\hline Married & 2 & & 50 & 2 & & 50 & & \\
\hline \multicolumn{9}{|l|}{$\begin{array}{l}\text { Socioeconomic } \\
\text { group }\end{array}$} \\
\hline B40 & 68 & & 64.2 & 38 & & 35.8 & 0.555 & 0.758 \\
\hline M40 & 70 & & 59.3 & 48 & & 40.7 & & \\
\hline T20 & 98 & & 61.3 & 62 & & 38.7 & & \\
\hline \multicolumn{9}{|c|}{ Marital status of parent } \\
\hline Married & 261 & & 61.4 & 164 & & 38.6 & 0.525 & 0.469 \\
\hline $\begin{array}{l}\text { Divorce/ } \\
\text { separated }\end{array}$ & 17 & & 54.8 & 14 & & 45.2 & & \\
\hline \multicolumn{9}{|l|}{ Smoking } \\
\hline No & 275 & & 61.1 & 175 & & 38.9 & 0.307 & 0.579 \\
\hline Yes & 3 & & 50 & 3 & & 50 & & \\
\hline \multicolumn{9}{|c|}{ Regular physical activity } \\
\hline No & 171 & & 57.6 & 126 & & 42.4 & 4.069 & 0.044 \\
\hline Yes & 105 & & 67.3 & 51 & & 32.7 & & \\
\hline \multicolumn{9}{|c|}{ Family member demise in the past six months } \\
\hline No & 254 & & 62.1 & 155 & & 37.9 & 2.159 & 0.142 \\
\hline Yes & 24 & & 51.1 & 23 & & 48.9 & & \\
\hline \multicolumn{9}{|c|}{ Family history of psychiatric disorder } \\
\hline No & 262 & & 62.2 & 159 & & 37.8 & 3.705 & 0.054 \\
\hline Yes & 16 & & 45.7 & 19 & & 54.3 & & \\
\hline \multicolumn{9}{|c|}{ Pages of Quran read per week median (IQR) } \\
\hline & 14 & & 14 & 10 & & 11 & & $<0.001^{\#}$ \\
\hline \multicolumn{9}{|c|}{ Days of Tahajjud prayer per week median (IQR) } \\
\hline & 1 & & 3 & 1 & & 1 & & $<0.001^{\#}$ \\
\hline
\end{tabular}


the student's activity as these interventions could improve the state of mind of the distressed students. ${ }^{21}$

Table III: Multiple logistic regression to determine factors associated with depression.

\begin{tabular}{|c|c|c|c|c|c|}
\hline \multirow{3}{*}{ Variables } & \multicolumn{5}{|c|}{ Multiple logistic regression } \\
\hline & & & & $95 \%$ & \\
\hline & Beta & Wald & AOR $^{+}$ & C.I \# & $\mathbf{P}$ \\
\hline \multicolumn{6}{|l|}{$\begin{array}{l}\text { Physical } \\
\text { activity }\end{array}$} \\
\hline \multicolumn{6}{|l|}{$\begin{array}{l}\text { No } \\
\text { (reference) }\end{array}$} \\
\hline Yes & -0.444 & 4.288 & 0.64 & $\begin{array}{l}0.42- \\
0.98\end{array}$ & $0.04 *$ \\
\hline Quran read & -0.005 & 1.167 & 0.99 & $\begin{array}{l}0.99- \\
1.00\end{array}$ & 0.28 \\
\hline $\begin{array}{l}\text { Tahajjud } \\
\text { prayer }\end{array}$ & -0.276 & 13.490 & 0.76 & $\begin{array}{l}0.66- \\
0.88 \\
\end{array}$ & $<0.001 *$ \\
\hline \multicolumn{6}{|c|}{$\begin{array}{l}* \mathrm{p}<0.05 \text { is significant, } \# 95 \% \text { confidence interval, }{ }^{+} \text {Adjusted Odd Ratio } \\
\text { Nagelkerke R Square was } 0.074 \text {. This implies that only } 7.4 \% \text { of variation in } \\
\text { this study was explained }\end{array}$} \\
\hline
\end{tabular}

\section{Discussion}

The prevalence of depression among IIUM medical students found in our study was $39 \%$ and it was lower compared to studies done in the middle east.7,8,10 Our study also had yield lower prevalence of depression compared to the studies done by the researchers from Management and Science University (MSU). ${ }^{12}$ However, compared to the findings from other public universities, prevalence of depression among medical students in our study was relatively higher. $11,12,14,16,20$ Differences in the results from other studies might be because there were varieties in term of assessment tools that were used, sample size, curriculum, and background of respondents. Apart from that, the prevalence of depression in the current study was similar to the previous study carried out in 2016 in IIUM. ${ }^{17}$ This should be a clear message, that even after three years, the prevalence was still the same indicating that something needs to be done to reduce the prevalence of depression amongst IIUM medical students. Early recognition of those with mental problems are very important. Continuous programme to provide mental and social support such as mentor-mentee programme should be emphasized. Teaching about coping mechanism should be part of the curriculum. Proven interventions such as online mindfulness and relaxation therapy to help students with depression, anxiety and stress should be embraced as part of the student's activity as these interventions could improve the state of mind of the distressed students. ${ }^{21}$

Our study revealed that those who practise regular physical exercise (AOR=0.66 CI 0.44-0.99, $\mathrm{p}=0.04$ ) had a lower risk of having depression compared to those who did not. It was inconsistent with a study done in a local private university where they found regular physical exercise did not have any correlation with depression. ${ }^{16}$ It was further supported by two previous studies in Egypt where the result also showed there was no significant association between regular physical exercise with depression. ${ }^{4,10}$ The data obtained by selfreporting method might be the reason behind this inconsistency. Perhaps, future study should use a validated assessment tool to assess for regular physical exercise and determine its association with depression. Despite inconsistent findings on the relationship between physical exercise and depression, this activity should still be strongly encouraged among medical students as it will also bring other benefits beyond just mental health benefit.22,23

We also found that Tahajjud prayer practiced were significantly associated with lower odds of having depression $(\mathrm{AOR}=0.76,95 \% \mathrm{CI}=0.66-0.88, \mathrm{p}<0.001)$. There was no previous study done to find the association between Tahajjud prayer and depression. However, a local study had reported that Tahajjud prayer practice as a single independent factor associated with better sleep quality ${ }^{24}$ which implied lower chance of depression as sleep quality is part of the symptoms related to depression. Hence, we believed that Tahajjud prayer practice should be encouraged to all Muslim students. Furthermore, we hoped future researcher will further explore the relationship of this variable with depression. Perhaps, there will be an assessment tool developed in the future that is able to measure the Islamic practices quantitatively.

Despite our study found that only physical exercise and Tahajjud prayer had significant association with depression, the fact is there are a lot more other factors that can contribute to depression. It is well known that multiple etiologic factors including genetic, biochemical, psychodynamic and socioenvironmental which may interact in complex ways to contribute to depression. Our study only focused mainly on socioenvironmental factors. Other factors such as personality, social support and access to internet were also among possible contributing factors not investigated in our study. It is strongly recommended for the future studies to include as many contributing factors related to depression. In addition, there were evidences that depression and anxiety were found to be persisted beyond the post-movement control order (MCO) during the Covid-19 pandemic. ${ }^{25,26}$ Factors contributing to these findings need to be addressed and managed accordingly. ${ }^{26}$ A similar study should be conducted during the Covid-19 pandemic which adds as another stressor hence the finding could be even worse and help should be provided to the students, post-MCO as necessary.

This limitation of the study was that the data obtained was through self-reporting which could be prone to recall bias. Other than that, there could also be reporting bias from the 
respondents about their Tahajjud prayer and Quran recitation practice. As this study also conducted using convenient sampling method, there is a risk for selection bias, however, since the response rate was high $(91.2 \%)$, it was still possible to generalise the data to all IIUM medical students. The strength of our study was that it was different from other previous studies as we included the Islamic practices component in which Tahajjud prayer practice was found to reduce the risk of depression.

\section{CONCLUSION}

In conclusion, the prevalence of depression among IIUM medical students in this current study was almost similar to the previous study in 2016. About $10 \%$ of current medical student had severe and extremely severe levels of depression. Authority needs to find effective measures to tackle this issue. We would like to suggest a regular discussion to educate the students not only how to deal with their own problems but also on how to react and interact with their friends who has mental health issues. Besides, our study found two protective factors against depression which were regular physical activity and Tahajjud prayer practice. Therefore, IIUM medical students should be encouraged to be more physical active and performed Tahajjud prayer more regularly.

\section{CONFLICT OF INTEREST}

There was no conflict of interest.

\section{ACKNOWLEDGEMENT}

The authors wish to thank all medical students who involved in this study for providing us cooperation to ensure success of this study.

\section{REFERENCES}

1. Kelley L. The World Health Organization (WHO). World Heal Organ. 2008;(September 2005):1-157.

2. Rotenstein LS, Ramos MA, Torre M, Bradley Segal J, Peluso MJ, Guille C, et al. Prevalence of depression, depressive symptoms, and suicidal ideation among medical students a systematic review and meta-analysis. JAMA - J Am Med Assoc. 2016;316(21):2214-36.

3. Russ TC, Stamatakis E, Hamer M, Starr JM, Kivimäki M, Batty GD. Association between psychological distress and mortality: Individual participant pooled analysis of 10 prospective cohort studies. BMJ. 2012;345 (7871):1-14.

4. Abdel Wahed WY, Hassan SK. Prevalence and associated factors of stress, anxiety and depression among medical Fayoum University students. Alexandria J of Med. 2017;53(1):77-84.

5. Ibrahim MB, Abdelreheem MH. Prevalence of anxiety and depression among medical and pharmaceutical students in Alexandria University. Alexandria J Med 2015;51(2):167-73.

6. Iqbal S, Gupta S, Venkatarao E. Stress, anxiety \& depression among medical undergraduate students \& their socio-demographic correlates. Indian J Med Res 2015;141:354-7.

7. Kulsoom B, Afsar NA. Stress, anxiety, and depression among medical students in a multiethnic setting. Neuropsychiatr Dis Treat. 2015 Jul 16;11:1713-22.

8. Rizvi F, Qureshi A, Rajput A, Afzal M. Prevalence of Depression, Anxiety and Stress (by DASS Scoring System) among Medical Students in Islamabad, Pakistan. Br J Med Med Res. 2015;8(1):69-75.

9. Qureshi MFH, Mohammad D, Sadiq S, Abubaker ZJ, Kumari U, Devnani J, et al. A comparative crosssectional analysis on prevalence of depression and associated risk factors among medical students and doctors of Karachi, Pakistan. Middle East Curr Psychiatry. 2020;27(1).

10. Fawzy M, Hamed SA. Prevalence of psychological stress, depression and anxiety among medical students in Egypt. Psychiatry Res. 2017 Sep;255:186-194.

11. Teh CK, Ngo CW, Aniyah R, Vellasamy R, Suresh K. Depression, Anxiety and Stress among Undergraduate Students: A Cross Sectional Study Choon. Open J Epidemioogy. 2015;5(November):260-8.

12. Fuad MDF, Mahdi B, Al-Zurfi N, Abdalqader MA, Baobaid MF, Elnajeh M, et al. Prevalence and Risk Factors of Depression Among Medical Students in a Malaysian Private University. Malaysian J Public Heal Med. 2016;16(3):87-92.

13. Fuad MD, Al-Zurfi BMN, Abdelqader MA, Abu Bakar MF, Elnajeh M, Abdullah MR. Prevalence and Risk Factors of Stress, Anxiety and Depression among Medical Students of a Private Medical University in Malaysia. Educ Med J. 2015;7(2).

14. Minhat $\mathrm{H}$, Abdalrheem T. Risks of mental problems among medical students in a public university in Malaysia. Malaysian J Med Heal Sci. 2019;15(SP3):65-9.

15. Gan GG, Hue YL. Anxiety, depression and quality of life of medical students in Malaysia. Med J Malaysia. 2019;74(1):57-61.

16. Ashraful Islam M, Yun Low W, Ting Tong W, Wan Yuen CC, Abdullah A. Factors Associated with Depression among University Students in Malaysia: A Cross-sectional Study. KnE Life Sci. 2018;4(4):415.

17. Radeef AS, Ghazi Faisal G. Depression, anxiety and stress with possible sources of stressors among 
undergraduate medical students in Malaysia. Brunei Int Med J. 2016;12(1):18-25.

18. Lovibond SH, Lovibond PF. Manual for the Depression Anxiety Stress Scales (2nd Edition). Sydney: Psychology Foundation of Australia; 1995

19. Henry JD, Crawford JR. The short-form version of the Depression Anxiety Stress Scales (DASS-21): Construct validity and normative data in a large non-clinical sample. Br J Clin Psychol. 2005;44:227-39.

20. Saravanan, C., Wilks R. Medical Students' Experience of and Reaction to Stress: The Role of Depression and Anxiety. The. Sci World J. 2014;2014:1.

21. Hatta Sidi. The psychological sequelae during mental health and Covid-19 Pandemic: Learning from the past for today's coping styles. Med and Health. June 2020;15 (1):1-4

22. Jamani NA, Said AH, Abd Aziz KH, Abd Rahman MA. Prevalence of Physical Activity and its Association with Body Mass Index Among Late Adolescents in Kuantan, Malaysia. Journal of International Dental and Medical Research 2019;12(4):1671-1675.

23. Said AH, Chia YC. Awareness, knowledge and practice of dyslipidaemia management among postgraduate primary care trainees in Malaysia: a cross-sectional study. BMJ Open 2017;7:e013573.

24. Said AH, Yusof MZ, Mohd FN, Azmi MANH, Mohd Hanapiah H, Abdullah AW. Poor sleep quality among medical students in International Islamic University Malaysia (IIUM) and its association with mental health and other factors. International Medical Journal Malaysia 2020;19(2):49-57.

25. Luke Sy-Cherng Woon, Hatta Sidi, Nik Ruzyanei Nik Jaafar and Mohammad Farris Iman Leong Abdullah. Mental Health Status of University Healthcare Workers during the COVID-19 Pandemic: A PostMovement Lockdown Assessment. Int. J. Environ. Res. Public Health 2020;17:9155.

26. Woon LS-C, Leong Bin Abdullah MFI, Hatta Sidi, Mansor NS, Nik Jaafar NR. Depression, anxiety, and the COVID-19 pandemic: Severity of symptoms and associated factors among university students after the end of the movement lockdown. PLos One 2021 16(5): e0252481. 